\title{
Morphological adaptation of rumen papillae during the dry period and early lactation as affected by rate of increase of concentrate allowance
}

\author{
K. Dieho, ${ }^{* 1}$ A. Bannink, † I. A. L. Geurts, ${ }^{*}$ J. T. Schonewille, † G. Gort,§ and J. Dijkstra* \\ *Animal Nutrition Group, Wageningen University, PO Box 338, 6700 AH Wageningen, the Netherlands \\ †Animal Nutrition, Wageningen UR Livestock Research, PO Box 338, $6700 \mathrm{AH}$ Wageningen, the Netherlands \\ łDepartment of Farm Animal Health, Faculty of Veterinary Medicine, Utrecht University, Yalelaan 7, 3584 CL Utrecht, the Netherlands \\ §Biometris, Wageningen University, PO Box 100, 6700 AC Wageningen, the Netherlands
}

\begin{abstract}
Knowledge of the morphological adaptation of rumen papilla, which plays an important role in volatile fatty acid absorption, in dry and early lactation dairy cattle is limited. Therefore, macro- and microscopic changes in papilla morphology during the dry period and lactation and the effect of rate of increase of concentrate allowance were studied. Samples were collected from 12 rumen-cannulated Holstein Friesian dairy cows during a pretreatment period, 50, 30, and $10 \mathrm{~d}$ antepartum (the dry period) and $3 \mathrm{~d}$ postpartum (pp), and a treatment period, 9, 16, 30, 44, 60, and $80 \mathrm{~d} \mathrm{pp}$. Cows had free access to either a dry period ration [27\% grass silage, $27 \%$ corn silage, $35 \%$ wheat straw, and $11 \%$ soybean meal on a dry matter (DM) basis] or a basal lactation ration ( $42 \%$ grass silage, $41 \%$ corn silage, and $17 \%$ soybean meal on a DM basis, and $0.9 \mathrm{~kg}$ of DM/d concentrate). Treatment consisted of either a rapid $(1.0 \mathrm{~kg}$ of DM/d; RAP; $\mathrm{n}=6)$ or gradual (0.25 kg of DM/d; GRAD; $\mathrm{n}$ $=6$ ) increase of concentrate allowance (up to $10.9 \mathrm{~kg}$ of $\mathrm{DM} / \mathrm{d}$ ), starting at d $4 \mathrm{pp}$, aimed at creating a contrast in rumen-fermentable organic matter (FOM) intake. Papillae were collected from the ventral, ventral blind, and dorsal blind rumen sacs and measured digitally. Intake of DM $(11.9 \mathrm{~kg} / \mathrm{d})$ and FOM $(5.7 \mathrm{~kg} / \mathrm{d})$ did not change during the pretreatment period, but increased during the treatment period to 24.5 and $15.0 \mathrm{~kg} / \mathrm{d}$ at 80 d pp, respectively. Concentrate treatment and sampling day interacted for FOM intake, which was $22 \%$ greater in RAP at $16 \mathrm{~d}$ pp compared with GRAD. Papilla surface area decreased during the pretreatment period by $19 \%$ to $28.0 \mathrm{~mm}^{2}$ at $3 \mathrm{~d} \mathrm{pp}$, thereafter increasing to 63.0 $\mathrm{mm}^{2}$ at $80 \mathrm{~d}$ pp. Concentrate treatment and sampling day interacted for surface area, which was greater in RAP compared with GRAD at 16 (46.0 vs. $\left.33.2 \mathrm{~mm}^{2}\right)$,
\end{abstract}

Received May 20, 2015.

Accepted November 22, 2015

${ }^{1}$ Corresponding author: kasper.dieho@wur.nl
30 (55.4 vs. $41.2 \mathrm{~mm}^{2}$ ), and 44 (60.5 vs. $49.7 \mathrm{~mm}^{2}$ ) days pp, showing that papillae can respond to a rapid rate of increase of FOM intake by increasing growth rate. Microscopic morphology was affected by sampling day, but neither by concentrate treatment nor by their interaction, with a decrease in papilla and epithelium thickness during the lactation. In conclusion, the rumen papillae respond to changes in FOM intake and the magnitude of this response depends on the rate of increase of FOM intake. This response in surface area of the rumen papillae potentially facilitates the absorption of the volatile fatty acids.

Key words: transition dairy cow, rumen papillae, rumen epithelium, rumen adaptation

\section{INTRODUCTION}

In ruminants, the reticulorumen is the major site for microbial fermentation of feed and, hence, production of VFA, which provide approximately $75 \%$ of total ME (Bergman, 1990). The luminal surface of the rumen wall is covered with papillae which increase the surface area for absorption of VFA. However, factors such as rumen VFA concentration and pH (Dijkstra et al., 1993), epithelial blood flow (Storm et al., 2012), and changes at the cellular level (Penner et al., 2011) may affect VFA absorption capacity as well. The absorption of VFA is seen as the primary process for maintaining rumen VFA concentration and $\mathrm{pH}$ within physiological limits, thereby supporting microbial fermentation of feed (Penner et al., 2009; Aschenbach et al., 2011; Dijkstra et al., 2012).

The proliferation of rumen papillae in young ruminants is triggered by the consumption of solid feed (Tamate et al., 1962; Sutton et al., 1963; Suárez et al., 2006), and thus associated with the intake of rumen fermentable organic matter (FOM) and its associated production of VFA. Furthermore, Dirksen et al. (1984) and Liebich et al. (1987) reported a positive relationship between the plane of nutrition and papilla surface area in the rumen. Therefore, it can be suggested that 
differences in surface area of rumen papilla are associated with differences in intake of FOM.

Currently, knowledge of macroscopic morphological changes of the rumen papillae (papilla surface area, length, and width) in dairy cows in the dry period until early lactation is limited (Shen et al., 2005; Malhi et al., 2013; Steele et al., 2015), or experiments have yielded inconclusive results (Reynolds et al., 2004). Likewise, knowledge about changes on the microscopic scale in rumen papilla (thickness of the papilla and epithelial layer) in the aforementioned period is limited as well. Diet- and time-related changes in thickness and organization of rumen epithelium have been reported by Dirksen et al. (1984), Liebich et al. (1987), Steele et al. (2011), and Bannink et al. (2012), but a comprehensive description of those changes during the dry period and early lactation is currently lacking (Martens et al., 2012). Therefore, the aim of the present experiment was to study macro- and microscopic morphological changes of rumen papillae from $50 \mathrm{~d}$ before expected calving date until $80 \mathrm{~d}$ postpartum in dairy cattle. After calving, 2 rates of increase of concentrate allowance were applied to create a contrast in FOM intake and evaluate its effect on morphological changes of the papillae. It was hypothesized that a rapid versus a gradual rate of increase of concentrate allowance creates a temporarily larger daily intake of FOM, inducing a greater rate of increase of surface area, length, and width of rumen papilla and a decrease in thickness of the papilla and its epithelial layer.

\section{MATERIALS AND METHODS}

The experimental procedures were approved by the Animal Care and Ethics Committee of Wageningen UR and conducted under the Dutch Law on Animal Experiments.

\section{Animals, Experimental Design and Management}

Three months before the start of the experiment 12 first-parity Holstein Friesian dairy cows were fitted with a rumen cannula (10 cm i.d., Bar Diamond Inc., Parma, ID). Eight weeks before the expected date of calving, cows were dried off and entered the experiment. The experiment had a randomized block design with repeated measurements. Cows were blocked by expected date of calving, and within each block cows were randomly assigned to either a rapid rate of increase of concentrate allowance or a gradual rate of increase of concentrate allowance. Samples were collected during the pretreatment period at 50,30, and $10 \mathrm{~d}$ antepartum (ap) and $3 \mathrm{~d}$ postpartum (pp), as well as during the treatment period at 9, 16, 30, 44,
60, and $80 \mathrm{~d}$ pp. Cows were milked at 0530 and 1530 $\mathrm{h}$, and milk yield was recorded daily. Each week milk samples from 4 consecutive milkings (same days every week) were analyzed for fat and protein content (ISO, 1999c; Qlip NV, Zutphen, the Netherlands). During the experiment, dry and lactating animals were housed in separate groups in a freestall barn with concrete slatted floor. Stalls were fitted with rubber mattresses covered with sawdust. On sampling days, cows were moved to a tiestall after the morning milking for the experimental procedures.

\section{Rations and Experimental Treatments}

Cows had free access to either a dry period ration or a basal lactation ration (Table 1) and free access to water throughout the experiment. Both rations had similar relative proportions of grass silage, corn silage and soybean meal (DM basis). In the dry period ration, however, chopped wheat straw was included to lower the energy density of the ration. The rations were mixed and fed once a day at $\sim 1000 \mathrm{~h}$. Concentrates were fed from calving onwards, with a daily allowance of $0.9 \mathrm{~kg}$ of $\mathrm{DM} / \mathrm{d}$, up to $3 \mathrm{~d} \mathrm{pp}$, irrespective of treatment. Thereafter, the concentrate treatment started and concentrate allowance was increased at either a rapid rate of $1.0 \mathrm{~kg}$ of $\mathrm{DM} / \mathrm{d}(\mathbf{R A P})$ or a gradual rate of $0.25 \mathrm{~kg}$ of DM/d (GRAD). Maximum concentrate allowance was set at $10.9 \mathrm{~kg}$ of $\mathrm{DM} / \mathrm{d}$, irrespective of rate of increase, and was achieved at 13 and $43 \mathrm{~d}$ pp for RAP and GRAD, respectively.

Daily intake of the dry period ration or the basal lactation ration $(\mathrm{kg} / \mathrm{d})$ was measured individually using feed bins (Insentec, Marknesse, the Netherlands), with a maximum stocking density of 2 cows/bin. Cows had access to all feed bins. Concentrate was fed using a concentrate dispenser (Manus VC5, DeLaval, Steenwijk, the Netherlands) and made the individual daily allowance available in equal portions over six 4-h periods and recorded the quantity actually dispensed $(\mathrm{kg} / \mathrm{d})$. Concentrate and ration ingredient samples were taken once a week. One sample of concentrate and one of each ration ingredient was immediately used for $\mathrm{DM}$ determination by forced-air oven drying $\left(105^{\circ} \mathrm{C}\right.$, $24 \mathrm{~h}$ ); the remaining samples were stored at $-20^{\circ} \mathrm{C}$ pending analyses. If necessary, basal ration formulation (on product basis) was adjusted for changes in ration ingredient DM content; DM content of concentrate was constant throughout the experiment.

After forced-air oven drying $\left(60^{\circ} \mathrm{C}, 24 \mathrm{~h}\right)$ and determination of DM (ISO, 1999b), feed samples were ground (1-mm screen) and pooled (each pool containing samples of 4 consecutive weeks) before determination crude ash (ISO, 2002), crude fat (ISO, 1999a), starch (ISO, 2004), 
Table 1. Basal ration composition, nutritional value, and chemical composition of rations and concentrate $(\mathrm{g} / \mathrm{kg}$ of $\mathrm{DM}$, unless stated otherwise)

\begin{tabular}{|c|c|c|c|}
\hline \multirow[b]{2}{*}{ Item } & \multicolumn{2}{|c|}{ Basal ration } & \multirow[b]{2}{*}{ Concentrate $^{1}$} \\
\hline & Dry period & Lactation & \\
\hline \multicolumn{4}{|l|}{ Ingredient } \\
\hline Grass silage $^{2}$ & 273 & 419 & \\
\hline Corn silage $^{3}$ & 270 & 414 & \\
\hline Soybean meal & 108 & 167 & \\
\hline Wheat straw & 349 & 0 & \\
\hline \multicolumn{4}{|l|}{ Chemical composition } \\
\hline $\mathrm{DM}, \mathrm{g} / \mathrm{kg}$ of product & 603 & 466 & 892 \\
\hline Crude ash & 80 & 75 & 68 \\
\hline $\mathrm{CP}$ & 109 & 157 & 178 \\
\hline Crude fat & 24 & 30 & 17 \\
\hline Starch & 90 & 139 & 248 \\
\hline Sugar & 44 & 67 & 95 \\
\hline NDF & 553 & 392 & 252 \\
\hline $\mathrm{ADF}$ & 325 & 235 & 115 \\
\hline ADL & 32 & 16 & 8 \\
\hline \multicolumn{4}{|l|}{ Calculated value ${ }^{4}$} \\
\hline $\mathrm{NE}_{\mathrm{L}}, \mathrm{MJ} / \mathrm{kg}$ of $\mathrm{DM}$ & 5.3 & 6.7 & 7.4 \\
\hline IDP & 57 & 90 & 114 \\
\hline $\mathrm{RDPB}$ & 3 & 14 & 10 \\
\hline FOM & 455 & 561 & 682 \\
\hline
\end{tabular}

${ }^{1}$ Concentrate composition (ingredients, $\mathrm{g} / \mathrm{kg}$ ): sugar beet pulp, 212; corn gluten, 200; barley, 150; wheat, 150; soybean meal, 120; citrus pulp, 100; molasses, 35; vinasse, 20; $\mathrm{CaCO}_{3}, 8$; salt, 3; and mineral premix, 2.

${ }^{2}$ Chemical composition of grass silage ( $\mathrm{g} / \mathrm{kg}$ of $\left.\mathrm{DM}\right)$ : crude ash, 105; CP, 110; crude fat, 31; sugars, 113; NDF, 497; ADF, 302; and ADL, 18.

${ }^{3}$ Chemical composition of corn silage ( $\mathrm{g} / \mathrm{kg}$ of $\mathrm{DM}$ ): crude ash, 44; CP, 64; crude fat, 31; starch, 330; NDF, 403; ADF, 231; and ADL, 17.

${ }^{4}$ Calculated values for grass and corn silage based on near-infrared spectrometry, Blgg AgroXpertus (Wageningen, the Netherlands). Calculated values for soybean meal and concentrate provided by Agrifirm Feed (Apeldoorn, the Netherlands). Calculated values for wheat straw obtained from CVB Feed Tables 2011 (CVB, 2011). NE values calculated according to the Dutch NE-system (Van Es, 1978). $\mathrm{IDP}=$ intestinal digestible protein; RDPB = rumen-degradable protein balance; FOM = fermentable organic matter; all calculated according to the Dutch DVE/OEB-system (Tamminga et al., 1994).

and sugars (van Vuuren et al., 1993). Crude protein was calculated from nitrogen $(\mathrm{N} \times 6.25)$ obtained by the Kjeldahl method (ISO, 2005). The NDF (with heat stable $\alpha$-amylase), ADF, and ADL were determined according to Van Soest et al. (1991) using an Ankom 2000 Fiber Analyzer (Ankom Technology Corp., Macedon, NY). The $\mathrm{NE}_{\mathrm{L}}$ was calculated according to Van Es (1978); intestinal digestible protein, RDP balance, and FOM were calculated according to Tamminga et al. (1994).

\section{Rumen Fluid Sampling and Papillae Collection}

Approximately $1 \mathrm{~h}$ after last access to the feed bins and, during lactation, the concentrate dispenser, a $200-\mathrm{mL}$ rumen fluid sample was taken from the ventral rumen sac using a stainless steel sampling probe $(2-\mathrm{mm}$ pore size). Immediately after collection, rumen fluid $\mathrm{pH}$ was measured and a $600-\mu \mathrm{L}$ aliquot was taken, acidified with $600 \mu \mathrm{L}$ of $5 \% \mathrm{H}_{3} \mathrm{PO}_{4}$ ( $\mathrm{vol} / \mathrm{vol}$ ), and subsequently stored at $-20^{\circ} \mathrm{C}$ pending analysis for acetic, propionic, and butyric acid concentration by GC as described by van Gastelen et al. (2015). Thereafter, rumen content solids were removed by hand and rumen liquid using a 1-L wide-mouth plastic jar. The rumen compartments were visually and manually inspected for remaining contents to ensure complete evacuation. The rumen contents were stored in an insulated tub and covered to prevent cooling until return into the rumen. Prior to the collection of rumen papillae, the rumen was washed twice with $10 \mathrm{~L}$ of tap water at $39^{\circ} \mathrm{C}$. After introduction, the warm water was manually scooped against the rumen wall of all compartments. After each wash, water was removed using a 1-L wide-mouth plastic jar.

Biopsies were taken from 3 sites in the rumen (Dirksen et al., 1984; Lesmeister et al., 2004; Bannink et al., 2012): the ventral rumen sac, directly opposite of the rumen cannula, $15 \mathrm{~cm}$ cranial of the caudal coronary pillar, and $20 \mathrm{~cm}$ below the dorsal limit of the papillae mat; the caudoventral blind rumen sac, opposite the rumen cannula, halfway between the dorsal and ventral limit of the caudoventral blind rumen sac, and $15 \mathrm{~cm}$ caudal of the ventral coronary pillar; and the caudodorsal blind rumen sac, opposite the rumen cannula halfway between the dorsal and ventral limit of the caudodorsal blind rumen sac, and $15 \mathrm{~cm}$ caudal of the dorsal coronary pillar (Dyce et al., 1996). Papillae were extracted from the rumen wall using forceps (No. 631319, Stuemer, Würzburg, Germany) and gently rinsed in $0.9 \% \mathrm{NaCl}$ solution before storage in buffered $4 \%$ formalin solution. In line with Odongo et al. (2006) and Steele et al. (2011, 2015), at least 6 intact papillae per site per cow per sampling day were collected. Papillae damaged by the biopsy forceps were easily recognized as damaged papillae, as they showed distinctive circular cut marks.

\section{Macroscopic Measurements}

For macroscopic measurements (per site per cow per sampling day), all papillae were photographed using a digital camera (Casio Exilim EX-Z70, Casio Computer Co., Tokyo, Japan), including a ruler in each photograph. The one-sided surface area of all papillae was measured using the Analyze Particles feature of ImageJ (Version 1.44n, National Institutes of Health, Bethesda, MD), comparable to the Geographical Information System (GIS) method described by Scocco et al. (2012). Length and width of all papillae was measured using ImageScope (Version 11.2.0.780, Aperio Technologies, Leica Biosystems, Nußloch, Germany). Papilla length 
was measured from the tip to the base of the papilla along its axis, papilla width was measured halfway of and perpendicular to the papilla length.

\section{Microscopic Measurements}

Five papillae per site per cow per sampling day (Odongo et al., 2006; Steele et al., 2011, 2015) were processed (minimum of 6 mo after collection and storage in $4 \%$ buffered formalin) for histological examination (Veterinary Pathology, Faculty of Veterinary Medicine, Utrecht University). After stepwise dehydration and paraffin infiltration, papillae were mounted parallel to each other before being fully embedded in paraffin. Longitudinal sections, 4- $\mu \mathrm{m}$ thick, perpendicular to the flat surface (median sagittal plane), were made halfway across the papilla width (coronal plane). Two consecutive sections were mounted on glass slides and stained with hematoxylin and eosin (Dobson et al., 1956; Andersen et al., 1999). Slides were digitized at $40 \times$ magnification (Department of Pathology, Utrecht Medical Center) using an Aperio ScanScope slide scanner (Aperio Technologies, Leica Biosytems). Complementary software was used for measurements (ImageScope Version 11.2.0.780, Aperio Technologies, Leica Biosytems). Starting at the top-left of the slide, each pair of papilla sections was evaluated for impairing artifacts and the first 3 suitable papillae were used for subsequent assessments.

1. Total thickness of the papilla (measured perpendicular to papilla length) at 250, 500, 750, and $1,000 \mu \mathrm{m}$ from the tip (Figure 1A).

2. Length of the luminal boundary of the stratum corneum and the length of the basal boundary of the stratum basale in 1,000 $\mu \mathrm{m}$ of papilla length, starting from the papilla tip (Figure 1B).

3. Total thickness of the papilla and thickness of the interstitium (both measured perpendicular to papilla length) was measured approximately halfway the papillae length, each 5 times with $250-\mu \mathrm{m}$ intervals in both directions over a total length of 1,000 $\mu \mathrm{m}$ (Figure $1 \mathrm{C}$ and D).

\section{Calculations and Statistical Analysis}

Daily DMI was calculated after correction for the weekly variation in DM content of ration components. For each sampling day, the reported DM and nutrient intakes are the averages of intakes recorded during the 3 preceding days.

For all papilla variables, averages were calculated per site per cow per sampling day [an average of 11.2 (SD
$=2.9$ ) papillae per site per cow per sampling day were collected]. Papilla surface area was calculated as $2 \times$ one-sided surface area as measured. The thickness of the epithelial layer was calculated from the difference in thickness of the total papilla and thickness of the interstitium. Average of papilla surface area growth $\left(\mathrm{mm}^{2} / \mathrm{d}\right)$ and daily change in FOM intake $(\mathrm{kg} / \mathrm{d})$ were calculated by dividing the difference in surface area and FOM intake by the difference in days for 2 consecutive sampling days. Total VFA concentration in rumen fluid was calculated as the sum of acetic, propionic, and butyric acid.

Papilla variables were assumed to be related to sampling day, biopsy site, and treatment. Milk production and feed intake were assumed to be related to sampling day and treatment, and milk fat and protein content were assumed to be related to sample week and treatment. Data on papilla variables were analyzed using the MIXED procedure in SAS 9.2 (SAS Institute Inc., Cary, NC) with the model (Littell et al., 2006):

$$
\begin{aligned}
Y_{i j k l}=\mu & +T_{i}+S_{k}+D_{l}+(T \times D)_{i l} \\
& +C_{j}+D(C)_{j l}+e_{i j k l},
\end{aligned}
$$

where variable $Y_{i j k l}$ was dependent on $\mu$ as the average experimental value and fixed main effects of concentrate treatment $T_{i}(i=\mathrm{RAP}, \mathrm{GRAD})$, sampling day $D_{l}(l=-50, \ldots, 80)$, site $S_{k}(k=$ ventral rumen sac, caudoventral blind rumen sac, caudodorsal blind rumen sac), and fixed interaction $(T \times D)_{i l}$. All other interactions were not significant and removed from the model. Cows, as experimental units, were represented with random effect $C_{j}(j=1, \ldots, 12)$. Furthermore, random effects of sampling day within cows $D(C)_{j l}$ were allowed, avoiding pseudo-replication due to multiple biopsy sites $S_{k}$. Errors $e_{i j k l}$ were assumed to be autocorrelated for repeated observations on the same cow and site using a spatial power covariance structure over sampling days (Littell et al., 1998). As concentrate treatment was only applicable to the treatment period (sampling d 9 to 80), the design could not be treated as a complete factorial design with respect to concentrate treatment and sampling day. The mixed model, however, was formulated as if a complete factorial design was in place, allowing treatment groups to differ before the treatment period. This structure was exploited by specifying custom hypotheses tests (ignoring default tests for main effects for sampling day, treatment, and their interaction, as made by PROC MIXED). Custom CONTRAST statements were constructed for: (1) the pretreatment period (sampling d -50 to 3 ), to compare the 2 future treatment groups, thereby evaluating the success of the random treatment allocation [neither dif- 
ferences between groups were expected, nor found $(P \geq$ $0.268)] ;(2)$ testing the treatment main effect, $T_{i}$ (averaged over sampling days), over the treatment period; (3) testing the sampling day main effect, $D_{l}$ (averaged over treatments), over the total experimental period; and (4) testing the interaction between treatment and sampling day, $(T \times D)_{i l}$, by testing sampling day by sampling day difference between concentrate treatment groups over the treatment period. To test specific hypotheses, CONTRAST and ESTIMATE statements were formulated to separate means. For analyses of feed intake, rumen $\mathrm{pH}$ and VFA, weekly milk production, milk fat and protein contents, papilla surface area by site, change in FOM intake, and change in papilla surface area, a simpler mixed model was used: fixed effect $S_{k}$ and random effect $D(C)_{j l}$ were removed, cow replaced site(cow) as subject of repeated measurement, and, where appropriate, $D_{l}$ was replaced by $W_{e e} k_{l}$. All results are reported as least squares means with their standard error unless indicated otherwise. Significance of effect was declared at $P<0.050$ and trends at 0.050 $\leq P<0.100$.
A

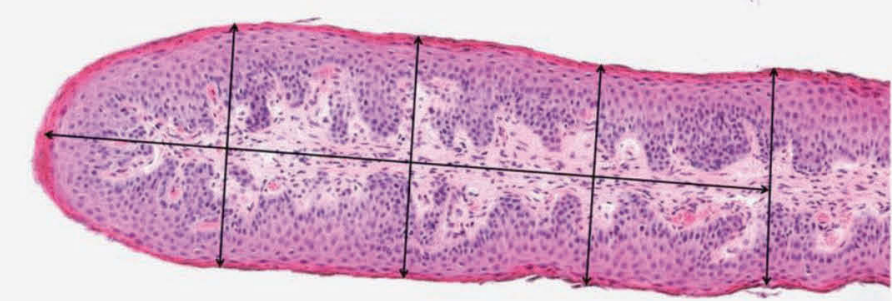

$200 \mu \mathrm{m}$
B

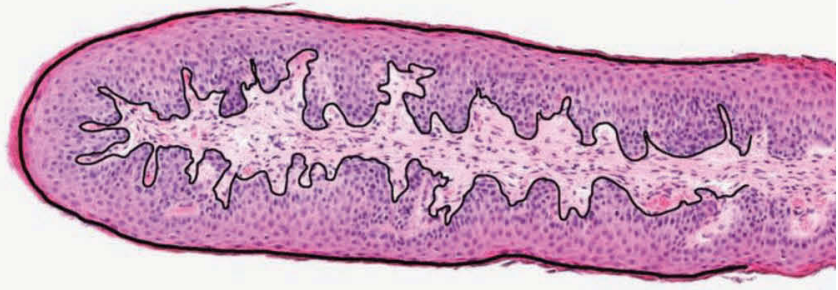

$200 \mu \mathrm{m}$

$\mathrm{C} 1$

$\mathrm{C} 2$
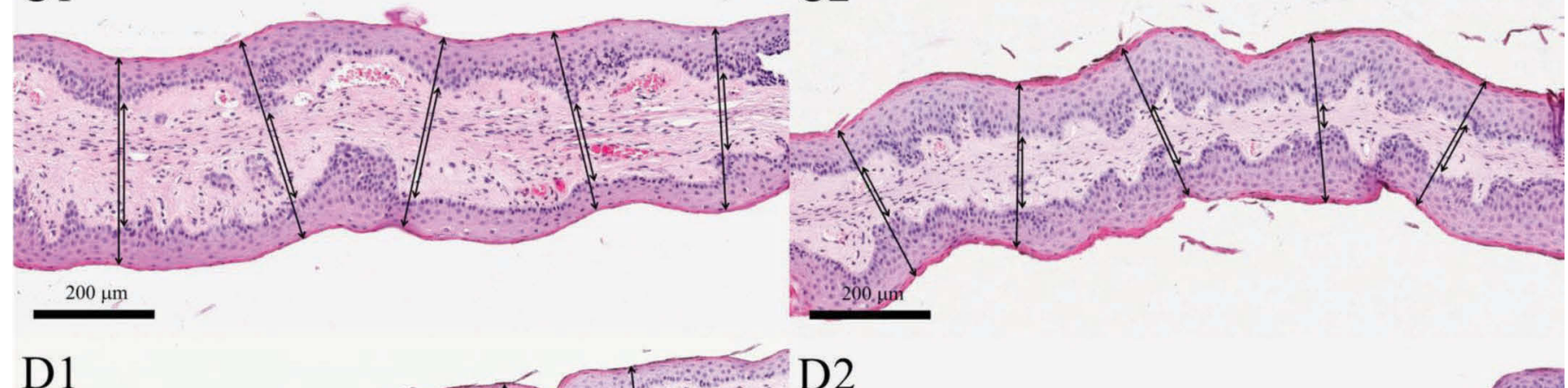

\section{D1}

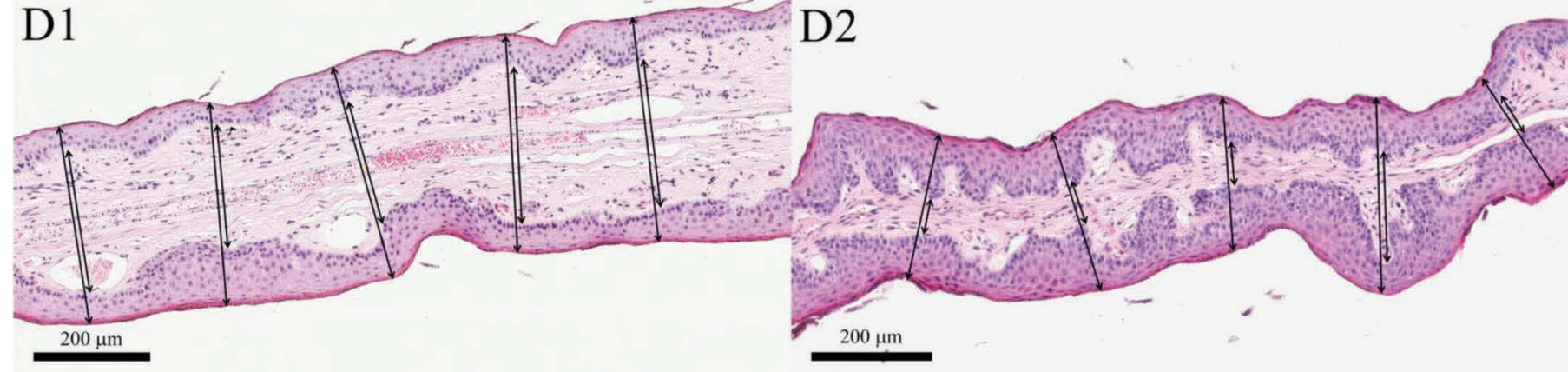

Figure 1. (A) Total thickness of the papilla at the tip (measured perpendicular to papilla length, indicated by vertical arrows) at 250,500 , 750 , and 1,000 $\mu \mathrm{m}$ from the tip. (B) Length of the luminal boundary of the stratum corneum (thick outer line) and the length of the basal boundary of the stratum basale (thin inner line) in 1,000 $\mu \mathrm{m}$ of papilla length, starting from the papilla tip. (C and D) Total thickness of the papilla in the middle and thickness of the interstitium (both measured perpendicular to papilla length, approximately halfway the papilla length), measured 5 times with $250-\mu \mathrm{m}$ intervals over a total length of 1,000 $\mu \mathrm{m}$. A and B represent papillae at $16 \mathrm{~d}$ postpartum; C1 and C2 represent papillae at $10 \mathrm{~d}$ antepartum for future gradual $(0.25 \mathrm{~kg}$ of DM/d; GRAD) and rapid (1.0 $\mathrm{kg}$ of DM/d; RAP) rate of increase of concentrate allowance groups, respectively; D1 and D2 represent papillae at 16 d postpartum for GRAD and RAP groups, respectively. All papillae shown were from the ventral rumen sac, $4-\mu \mathrm{m}$ thick section, with hematoxylin eosin stain. Color version available online. 


\section{RESULTS}

All cows completed the experiment. One cow in group GRAD calved earlier than expected and missed sampling at $10 \mathrm{~d}$ ap; otherwise all samples could be collected. Average (SD) actual sampling days were 46.3 (5.1), 26.5 (5.7), and 8.6 (3.4) d ap for the pretreatment and $3.0(0.0) \mathrm{d}$ pp and $9.0(0.0), 16.1(0.3), 30.2(0.3)$, $44.2(0.4), 60.0(0.9)$, and $79.3(2.2) \mathrm{d}$ pp for the treatment period. One animal was treated for mastitis (from RAP) and 7 were treated for (chronic) endometritis (4 from RAP, 3 from GRAD). All animals reacted favorably to veterinary treatment and followed their experimental treatments and sampling schedule as planned. The rapid or gradual rate of increase of concentrate allowance was readily accepted by all cows.

\section{Intake of DM and Macronutrients}

Intake of DM and macronutrients is presented in Table 2; in addition, daily DMI is shown in Figure 2A. Total DMI was affected by sampling day $(P<0.001)$. During the pretreatment period total DMI remained similar over the sampling days $(P=0.277)$, and dur- ing the pretreatment period future RAP and GRAD groups showed no differences in total DMI $(P=0.416)$ or, consequently, in intake of FOM, starch, sugars, and $\mathrm{NE}_{\mathrm{L}}(P \geq 0.325$; data not shown $)$. In the treatment period, total DMI increased from 3 to $30 \mathrm{~d}$ pp for group RAP and tended to increase further to $80 \mathrm{~d}$ pp $(P=$ 0.062). For group GRAD, DMI increased to $44 \mathrm{~d}$ pp $(P \leq 0.004)$, remaining similar thereafter. Total DMI was neither affected by the concentrate treatment nor by an interaction between concentrate treatment and sampling day. Concentrate treatment, sampling day, and their interaction affected DMI of the basal ration, which was higher for group GRAD at 9, 16, and $30 \mathrm{~d}$ $\mathrm{pp}$, respectively $(P \leq 0.015)$. In group RAP, DMI from the basal ration was $21.2 \%$ lower $(P \leq 0.006)$ at $16 \mathrm{~d} p \mathrm{pp}$ compared with 9 or $30 \mathrm{~d}$ pp, whereas this decrease was not observed in group GRAD $(P \geq 0.156)$.

In the treatment period, FOM intake was affected by sampling day $(P<0.001)$; in contrast to total DMI, an interaction between concentrate treatment and sampling day was observed $(P<0.001)$. Intake of FOM was $21.8 \%$ greater in group RAP than group GRAD at $16 \mathrm{~d}$ pp $(P<0.001)$. From $30 \mathrm{~d}$ pp onwards, FOM intake was similar for RAP and GRAD, but at $60 \mathrm{~d}$

Table 2. Least square means of feed intake ${ }^{1}(\mathrm{~kg} / \mathrm{d}$ unless otherwise noted) for rapid rate of increase $(1.0 \mathrm{~kg}$ of $\mathrm{DM} / \mathrm{d})$ of concentrate allowance $(\mathrm{RAP} ; \mathrm{n}=6)$ and gradual rate of increase $(0.25 \mathrm{~kg} \mathrm{DM} / \mathrm{d})$ of concentrate allowance $(\mathrm{GRAD} ; \mathrm{n}=6)$ treatments

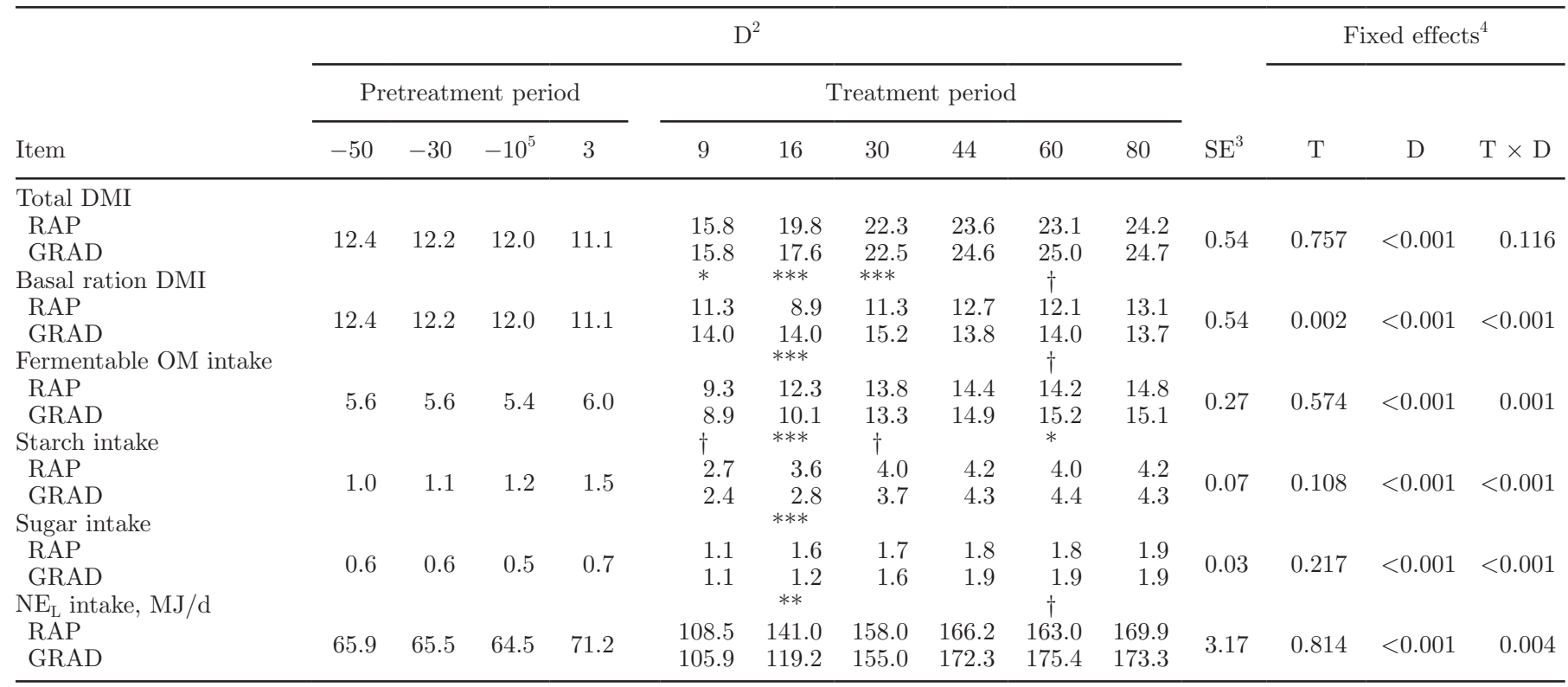

${ }^{1}$ Reported mean is calculated over the $3 \mathrm{~d}$ preceding the sampling day.

${ }^{2} \mathrm{D}=$ sampling day relative to calving.

${ }^{3}$ Standard error for LSM by sampling day; $\mathrm{n}=12$.

${ }^{4} \mathrm{~T}=$ treatment, $P$-value for treatment period (d 9 to 80$) ; \mathrm{D}=$ sampling day, $P$-value for pretreatment and treatment period $(\mathrm{d}-50$ to 80 ); $\mathrm{T} \times \mathrm{D}=P$-value for treatment period $(\mathrm{d} 9$ to 80$)$.

${ }^{5}$ Group GRAD: $\mathrm{n}=5,1$ cow had no measurement at $\mathrm{d}-10$ due to early calving.

$\dagger P<0.100,{ }^{*} P<0.050,{ }^{* *} P<0.010,{ }^{* * *} P<0.001$, significance of difference in LSM of RAP or GRAD for the same sampling day and variable. 

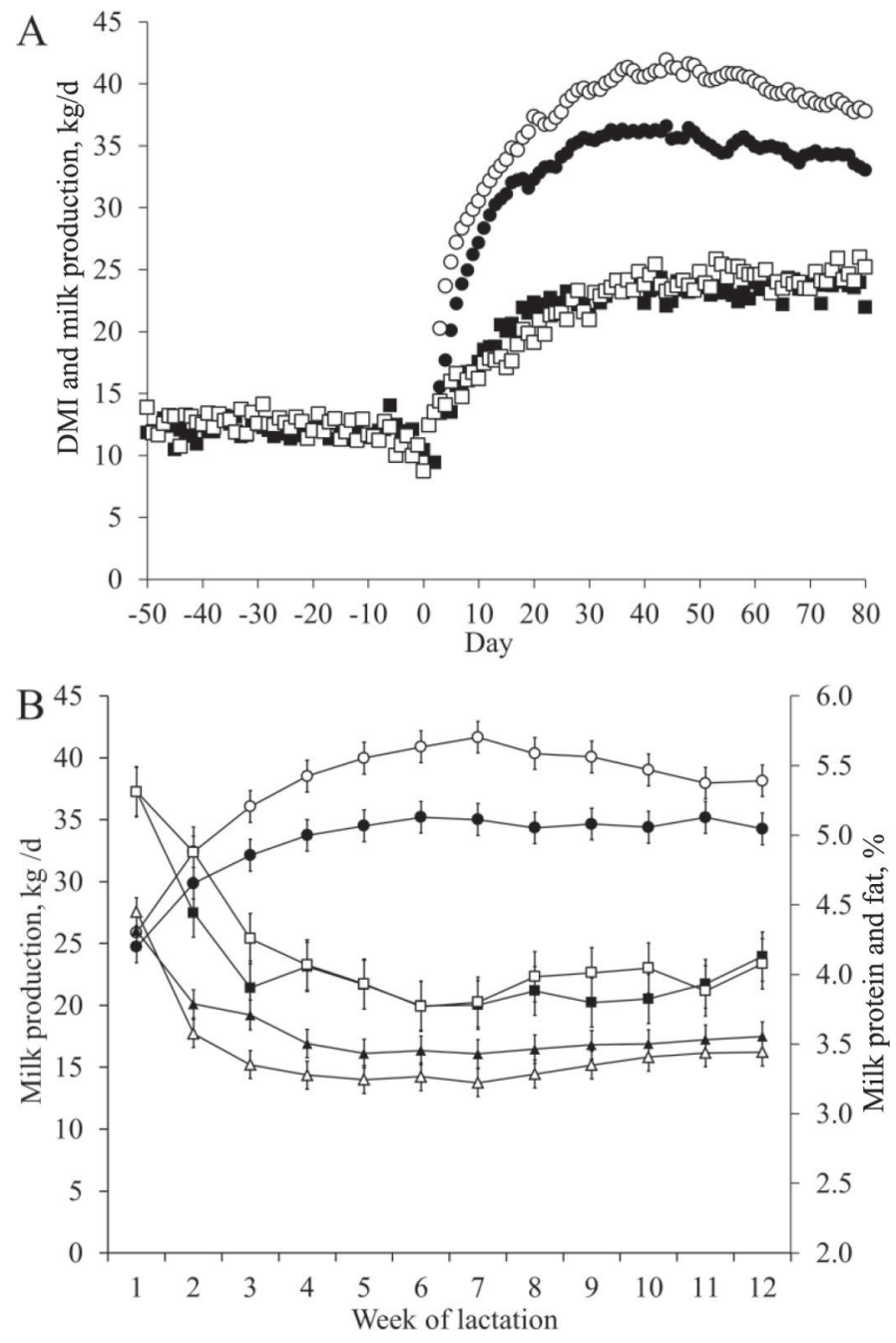

Figure 2. (A) Average intake of DM (kg/d; $\square$ ) or milk production $(\mathrm{kg} / \mathrm{d}$; $\bigcirc)$ for a rapid $(1.0 \mathrm{~kg}$ of $\mathrm{DM} / \mathrm{d}$; RAP, $\boldsymbol{\bullet}, \mathrm{n}=6)$ or gradual $(0.25 \mathrm{~kg}$ of DM/d; GRAD, $\square \mathrm{O}, \mathrm{n}=6)$ rate of increase of concentrate allowance postpartum. (B) Average milk production $(\mathrm{kg} / \mathrm{d}$; $\bullet$ ), milk fat content $(\% ; \square)$, or milk protein content $(\% ; \boldsymbol{\Delta} \Delta)$ by lactation week for a rapid (1.0 kg of DM/d; RAP, $\boldsymbol{\square} \mathbf{\Delta}, \mathrm{n}=6)$ or gradual $(0.25 \mathrm{~kg}$ of $\mathrm{DM} / \mathrm{d}$; GRAD, $\bigcirc \square \Delta, \mathrm{n}=6)$ rate of increase of concentrate allowance postpartum. Values represent average of 4 consecutive milkings; 2 milkings/d. Day $=$ day relative to calving. Values represent $\mathrm{LSM} \pm \mathrm{SE}$.

pp tended to be greater for GRAD than RAP $(P=$ 0.062 ). The intake of starch, sugar, and $\mathrm{NE}_{\mathrm{L}}$ was affected by sampling day $(P<0.001)$, and an interaction between concentrate treatment and sampling day $(P \leq$ 0.004 ) was observed. Intake of starch, sugar, and $\mathrm{NE}_{\mathrm{L}}$ was greater for group RAP at $16 \mathrm{~d}$ pp $(P \leq 0.001)$, and starch intake tended to be greater at 9 and $30 \mathrm{~d}$ pp $(P \leq 0.083)$ compared with group GRAD. At 60 $\mathrm{d}$ pp, starch intake was higher $(P=0.014)$ and $\mathrm{NE}_{\mathrm{L}}$ tended $(P=0.055)$ to be higher in GRAD compared with RAP.

\section{Milk Production}

Daily milk production is shown in Figure 2A and weekly milk production by week in Figure 2B. Weekly milk production increased during the treatment period $(P<0.001)$ and tended to be less $(P=0.067)$ in group RAP $(33.2 \pm 1.3 \mathrm{~kg} / \mathrm{d})$ than group GRAD (37.6 \pm $1.3 \mathrm{~kg} / \mathrm{d}$ ). No interaction between concentrate treatment and week was observed for milk production $(P$ $=0.416)$. Weekly average milk production, expressed as fat- and protein-corrected milk $(\mathrm{kg} / \mathrm{d})$, was less $(P$ $=0.033)$ in group RAP $(34.0 \pm 1.1 \mathrm{~kg} / \mathrm{d})$ than group GRAD $(38.3 \pm 1.1 \mathrm{~kg} / \mathrm{d}$; data not shown), whereas no interaction between concentrate treatment and week was observed.

Both milk protein and milk fat content (Figure 2B) were affected by week and decreased in wk 1 through $4(P<0.001)$. During wk 5 through 12 , milk protein and milk fat contents did not vary $(P \geq 0.161)$. Milk protein content was similar between treatments $(P=$ 0.174 ), averaging $3.52 \pm 0.07 \%$, and an interaction between concentrate treatment and week for milk protein content was observed $(P=0.034)$. Milk protein content in group RAP $(3.71 \%)$ was greater $(P=0.024)$ in wk 3 compared with group GRAD (3.35\%). Milk fat content (Figure 2B) averaged $4.12 \pm 0.12 \%$ and was neither affected by concentrate treatment nor by its interaction with week $(P \geq 0.590)$.

\section{Rumen Content Mass, VFA Concentration, and pH}

Rumen content mass (solids and liquid) was affected by sampling day, increasing from $64.5 \pm 2.8 \mathrm{~kg}$ during the pretreatment to $77.2 \pm 2.8 \mathrm{~kg}$ during the treatment period $(P<0.001)$, but was not affected by concentrate treatment $(P=0.826)$ nor its interaction with sampling day $(P=0.154)$. Total VFA $(\mathrm{m} M)$ and rumen fluid $\mathrm{pH}$ (Figure 3A) were affected by sampling day $(P<$ 0.001). Total rumen VFA concentration increased during the pretreatment period $(P=0.011)$, whereas $\mathrm{pH}$ decreased $(P<0.001)$. Total VFA averaged $79.5 \pm 5.2$ $\mathrm{m} M$ during the dry period, -50 to $-10 \mathrm{~d}$ ap, increasing to $96.4 \pm 5.2 \mathrm{~m} M$ at $3 \mathrm{~d}$ pp $(P=0.002)$, whereas fluid $\mathrm{pH}$ averaged $6.71 \pm 0.09$ during the dry period and decreased to $6.27 \pm 0.09$ at $3 \mathrm{~d}$ pp $(P<0.001)$. In the treatment period, total VFA increased to $120 \pm 5.2 \mathrm{mM}$ at $44 \mathrm{~d} \mathrm{pp}(P<0.001)$, whereas $\mathrm{pH}$ tended to decrease to $6.07 \pm 0.09$ at $44 \mathrm{~d}$ pp $(P=0.097)$; thereafter both remained similar up to $80 \mathrm{~d}$ pp. Neither total VFA nor $\mathrm{pH}$ were affected by concentrate treatment $(P \geq 0.538)$ nor its interaction with sampling day $(P \geq 0.289)$.

The molar proportions of acetic, propionic, and butyric acid in the rumen fluid (Figure 3B) were affected by sampling day $(P<0.001)$. Molar proportion of ace- 
tic acid was larger $(P<0.001)$ during the pretreatment period compared with the treatment period $(718 \pm 7$ vs. $645 \pm 7 \mathrm{mmol} / \mathrm{mol}$, respectively), whereas the molar proportions of propionate and butyrate were smaller $(P<0.001)$ during the pretreatment period $(181 \pm 7$ and $101 \pm 3 \mathrm{mmol} / \mathrm{mol}$, respectively) compared with the treatment period $(236 \pm 7$ and $119 \pm 3 \mathrm{mmol} / \mathrm{mol}$, respectively). An interaction was observed between concentrate treatment and sampling day for molar pro-
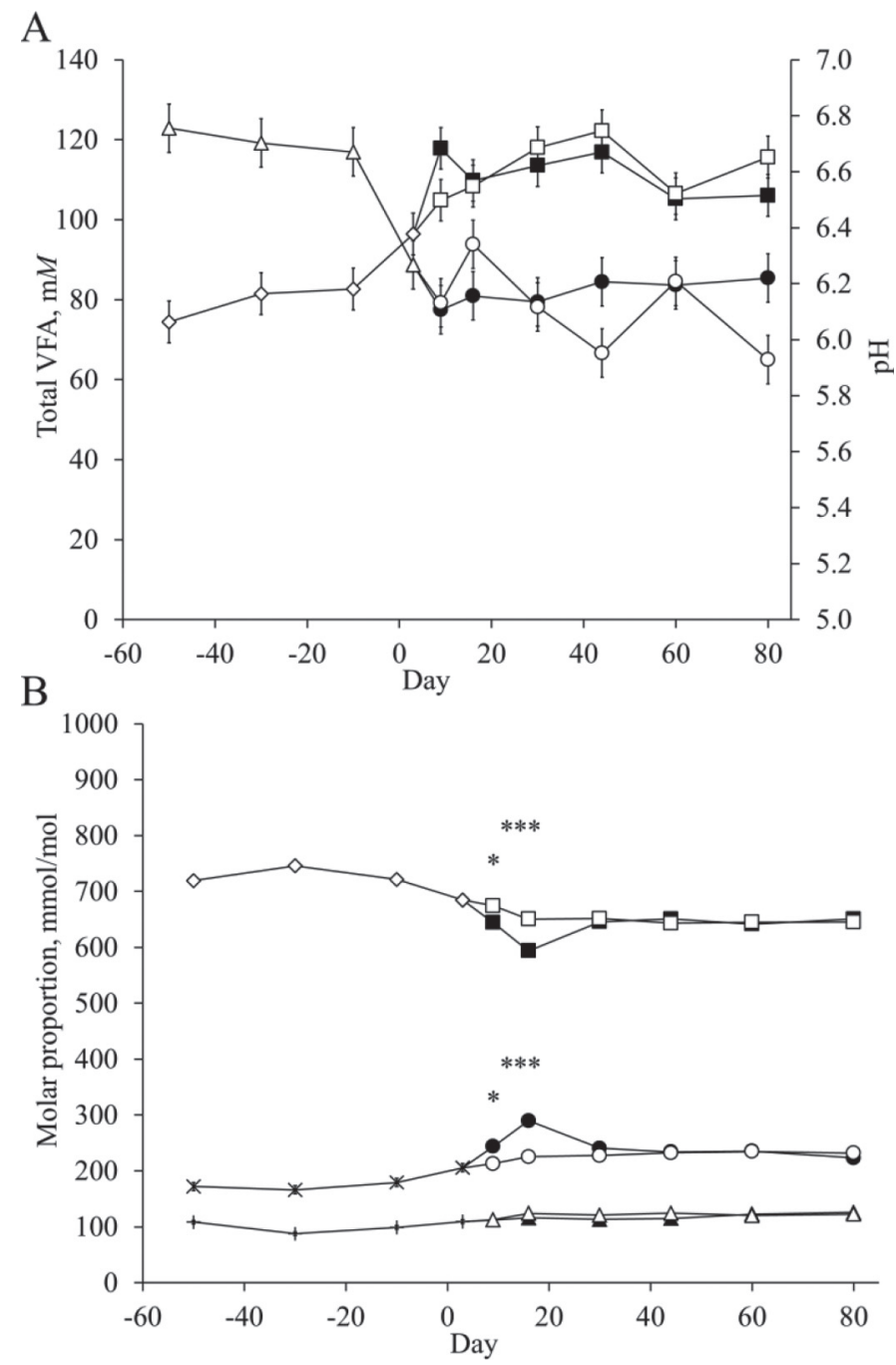

Figure 3. (A) Average of total VFA concentration $(\mathrm{m} M ; \diamond \square \square)$ or $\mathrm{pH}(\Delta \odot)$ in the pretreatment period $(\diamond \Delta ; \mathrm{n}=12)$ and in the treatment period for a rapid $(1.0 \mathrm{~kg}$ of $\mathrm{DM} / \mathrm{d}$; RAP, $\boldsymbol{\nabla}, \mathrm{n}=6)$ and gradual $(0.25 \mathrm{~kg}$ of $\mathrm{DM} / \mathrm{d}$; GRAD, $\square \mathrm{O}, \mathrm{n}=6)$ rate of increase of concentrate allowance postpartum. (B) Molar proportions (mmol/ mol) of acetic $(\diamond \square \square)$, propionic $(\times \bullet)$, or butyric acid $(+\Delta \Delta)$ in the pretreatment period $(\diamond \times+; \mathrm{n}=12)$ and in the treatment period for a rapid $(1.0 \mathrm{~kg}$ of $\mathrm{DM} / \mathrm{d} ; \mathrm{RAP}, \boldsymbol{\square} \mathbf{\Delta}, \mathrm{n}=6)$ and gradual $(0.25 \mathrm{~kg}$ of $\mathrm{DM} / \mathrm{d}$; GRAD, $\bigcirc \square \Delta, \mathrm{n}=6$ ) rate of increase of concentrate allowance postpartum. Day $=$ day relative to calving. Values represent LSM \pm SE. ${ }^{*} P<0.050,{ }^{* * *} P<0.001$, significance of difference in LSM of RAP or GRAD. portions of acetic and propionic acid $(P \leq 0.003)$, but not for butyric acid $(P=0.501)$. The molar proportion of acetic acid in group RAP was 4.5 and $8.7 \%$ lower at 9 and $16 \mathrm{~d}$ pp, respectively, compared with group GRAD, with an opposite effect for molar proportion of propionic acid.

\section{Macroscopic Rumen Papillae Assessment}

Papilla surface area (Table 3) was affected by sampling day $(P<0.001)$. During the pretreatment period, papilla surface area decreased by $18.6 \%(P=0.018)$, caused by a $17.8 \%$ decrease $(P<0.001)$ in papilla width. The future RAP and GRAD groups showed neither a difference in papilla surface area $(P=0.520)$ nor in length or width $(P \geq 0.268$; data not shown) in the pretreatment period. More specifically, at $3 \mathrm{~d}$ $\mathrm{pp}$, the day before starting the concentrate treatment, papilla surface area was similar for RAP and GRAD $(P=0.306)$, as were papilla length and width $(P \geq$ 0.156). During the treatment period, papilla surface area increased by $125 \%$ from $28.0 \mathrm{~mm}^{2}$ at $3 \mathrm{~d}$ pp to 63.0 $\mathrm{mm}^{2}$ at $80 \mathrm{~d} \mathrm{pp}(P<0.001)$. Concentrate treatment interacted with sampling day for papilla surface area $(P$ $=0.011)$ and from 16 through $44 \mathrm{~d}$ pp papilla surface area was larger in group RAP $(P \leq 0.013)$ compared with GRAD.

Papilla length increased by 39\% $(P<0.001)$ and width by $50 \%(P<0.001)$ from 3 to $80 \mathrm{~d}$ pp. Papilla length tended to be affected by concentrate treatment $(P=0.058)$ without concentrate treatment interacting with sampling day, whereas papilla width was affected by concentrate treatment $(P=0.041)$ and by an interaction between concentrate treatment and sampling day $(P=0.020)$. Group RAP had wider papillae at 16 and $30 \mathrm{~d} p p(P \leq 0.035)$ and tended to have wider papillae at $44 \mathrm{~d}$ pp $(P=0.053)$ when compared with GRAD.

Between sampling sites, papilla surface area differed (Figure $4 ; P=0.001$ ). Papillae from the ventral rumen sac $\left(46.0 \pm 1.9 \mathrm{~mm}^{2}\right)$ had a larger surface area $(P$ $\leq 0.017)$ compared with the ventral blind $(39.3 \pm 1.9$ $\left.\mathrm{mm}^{2}\right)$ and dorsal blind $\left(41.8 \pm 1.9 \mathrm{~mm}^{2}\right)$ rumen sacs, which did not differ $(P=0.160)$. All sites were affected by sampling day $(P<0.001)$ and showed a similar development of papilla surface area. Concentrate treatment affected the papilla surface area in the ventral rumen sac and the dorsal blind rumen sac $(P \leq 0.031)$, but did not affect the area in the ventral blind rumen $\operatorname{sac}(P=0.105)$. A tendency for an interaction between concentrate treatment and sampling day was observed for papilla surface area in the ventral rumen sac $(P=$ $0.068)$, but not in the ventral blind rumen $\operatorname{sac}(P=$ $0.140)$ and the dorsal blind rumen sac $(P=0.159)$. 
Table 3. Least square means of papilla surface area, length, and width for rapid rate of increase (1.0 $\mathrm{kg}$ of DM/d) of concentrate allowance $(\mathrm{RAP} ; \mathrm{n}=6)$ and gradual rate of increase $(0.25 \mathrm{~kg}$ of $\mathrm{DM} / \mathrm{d})$ of concentrate allowance $(\mathrm{GRAD} ; \mathrm{n}=6)$ treatments

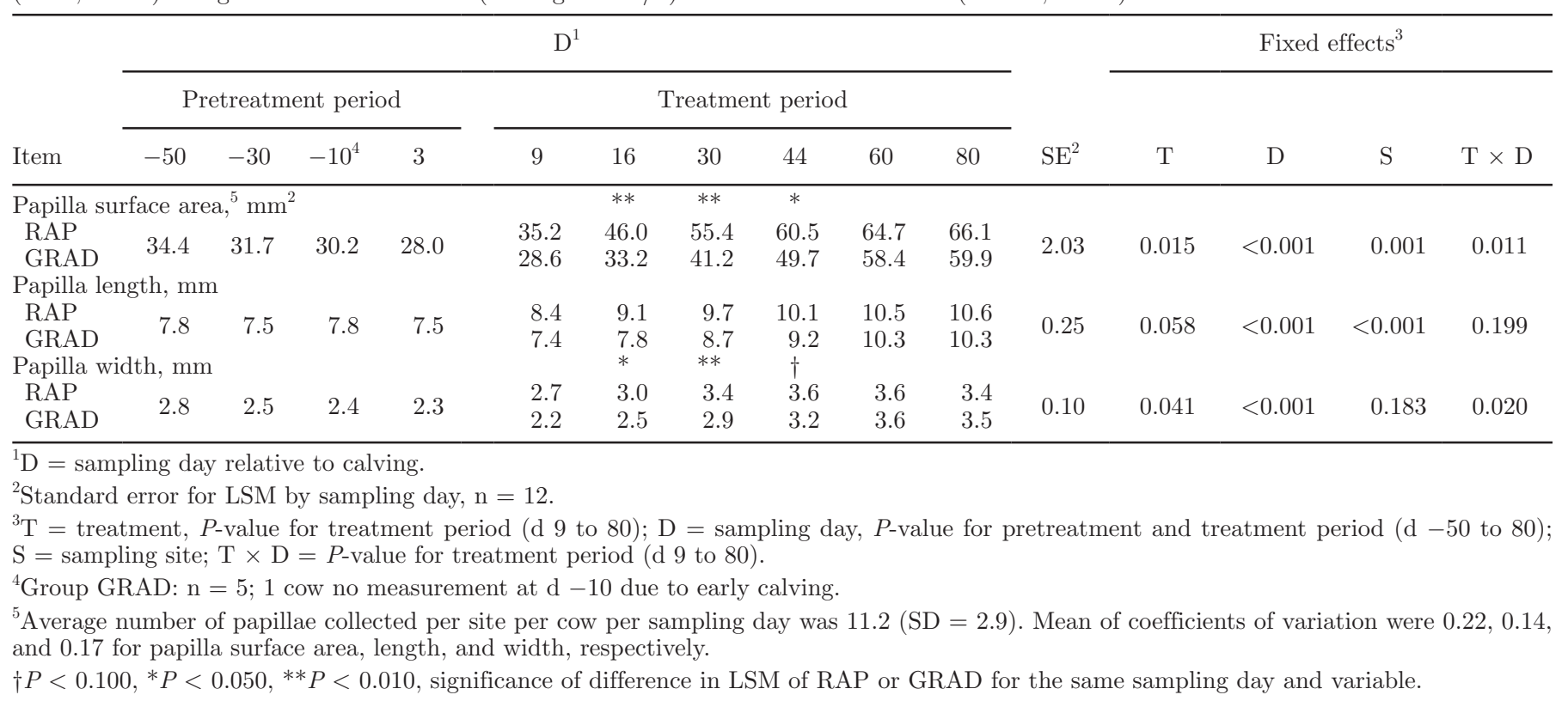

\section{Microscopic Rumen Papillae Assessment}

Thickness of the rumen papillae at the tip and in the middle, thickness of the epithelium in the middle, and stratum basale-to-stratum corneum ratio (Table 4) were affected by sampling day $(P \leq 0.002)$. During the pretreatment period total papilla thickness at the middle, epithelial thickness at the middle, and stratum basale-to-stratum corneum ratio increased $(P \leq 0.027)$; the future RAP and GRAD groups showed no differences for any of the microscopic papilla variables $(P \geq$ 0.289; data not shown). In the treatment period, total papilla thickness at the tip and at the middle, epithelial thickness at the middle, and stratum basale-to-stratum corneum ratio decreased $(P \leq 0.002)$. Papilla thickness at the tip and the stratum basale-to-stratum corneum ratio were higher at $9 \mathrm{~d}$ pp compared with $3 \mathrm{~d}$ pp $(P$ $<0.001)$. Neither concentrate treatment $(P \geq 0.306)$ nor an interaction between concentrate treatment and sampling day affected the microscopic papilla variables $(P \geq 0.330)$.

\section{Dynamics in FOM intake and of the Papillae Surface Area}

Change in daily FOM intake (Figure 5A) was affected by sampling day $(P<0.001)$. During the pretreatment period, variation in change in daily FOM intake was minimal $(P=0.195)$ and averaged $0.01 \pm 0.03 \mathrm{~kg} / \mathrm{d}$, and the future treatment groups did not reveal differences in change in daily FOM intake $(P=0.713$; data not shown). In the treatment period, the change in daily FOM intake was greatest between 3 to $9 \mathrm{~d}$ pp for RAP and GRAD $(P \leq 0.004)$. Thereafter, the change in daily FOM intake decreased and was approximately zero between 44 to $60 \mathrm{~d}$ pp and onwards. Change in daily FOM intake was not affected by concentrate treatment $(P=0.124)$, but an interaction between concentrate treatment and sampling day existed $(P<0.001)$. The change in daily FOM intake was greater in group RAP than group GRAD between 3 to $9 \mathrm{~d}$ pp (0.59 vs. 0.46 $\pm 0.03 \mathrm{~kg} / \mathrm{d}$, respectively; $P<0.001$ ), and between 9 to $16 \mathrm{~d}$ pp (0.42 vs. $0.17 \pm 0.03 \mathrm{~kg} / \mathrm{d}$, respectively; $P=$ 0.018). Between 16 to $30 \mathrm{~d} \mathrm{pp}$, the change in daily FOM intake decreased to $0.10 \pm 0.03 \mathrm{~kg} / \mathrm{d}$ for group RAP and was lower than that for group GRAD with $0.23 \pm$ $0.03 \mathrm{~kg} / \mathrm{d}(P=0.018)$. In group GRAD, change in daily FOM intake decreased from $0.23 \pm 0.03 \mathrm{~kg} / \mathrm{d}$ at 16 to $30 \mathrm{~d}$ to $0.02 \pm 0.03 \mathrm{~kg} / \mathrm{d}$ between 44 and $60 \mathrm{~d}$ pp $(P<$ $0.001)$, remaining similar thereafter $(P=0.619)$.

Change in papilla surface area (Figure 5B) was affected by sampling day $(P<0.001)$. During the pretreatment period, change in papilla surface area averaged $-0.13 \pm 0.13 \mathrm{~mm}^{2} / \mathrm{d}$, and the future treatment groups did not reveal differences in in change in papilla surface area $(P=0.335)$. The treatment period showed an interaction between concentrate treatment and sampling day $(P=0.013)$, but overall change in papilla surface area was not affected by concentrate treatment $(P=0.169)$. Change in papilla surface area was greater $(P<0.001)$ between 9 to $16 \mathrm{~d}$ pp in group RAP compared with GRAD, at 1.51 versus $0.66 \pm 0.13 \mathrm{~mm}^{2} / \mathrm{d}$, 

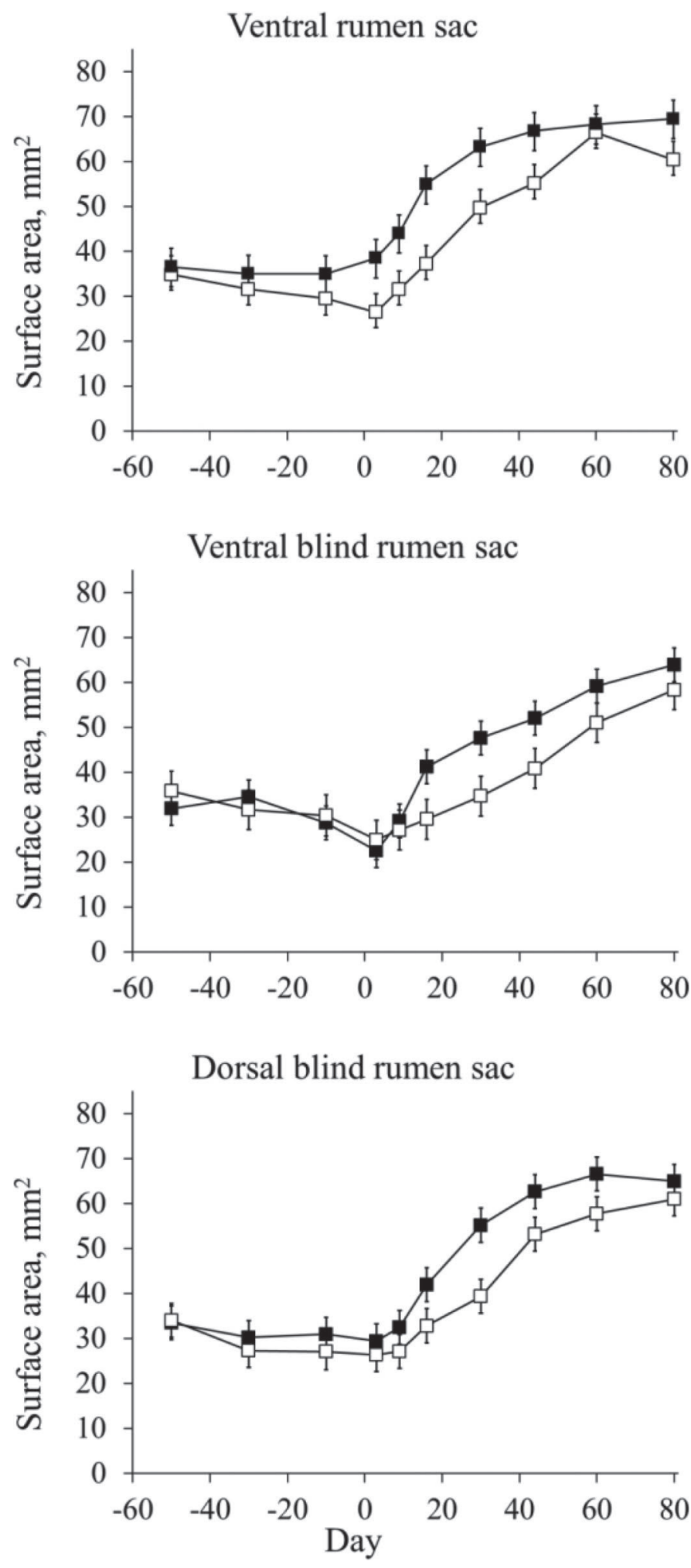

Figure 4. Papilla surface area $\left(\mathrm{mm}^{2}\right)$ at the 3 rumen sampling sites for a rapid $(1.0 \mathrm{~kg}$ of $\mathrm{DM} / \mathrm{d}$; RAP, $\mathbf{\square}, \mathrm{n}=6)$ and gradual $(0.25 \mathrm{~kg}$ of $\mathrm{DM} / \mathrm{d}$; GRAD, $\square, \mathrm{n}=6$ ) rate of increase of concentrate allowance postpartum. Day $=$ day relative to calving. Values represent LSM \pm SE.

Journal of Dairy Science Vol. 99 No. 3, 2016 respectively. After this peak for group RAP, change in papilla surface area gradually declined to $0.09 \mathrm{~mm}^{2} / \mathrm{d}$ between 60 to $80 \mathrm{~d}$ pp. In group GRAD, change in papilla surface area was similar $(P=0.868)$ from 3 to $9 \mathrm{~d}$ pp through the 44 to $60 \mathrm{~d}$ pp interval, averaging $0.57 \pm 0.13 \mathrm{~mm}^{2} / \mathrm{d}$, and growth declined to $0.06 \pm 0.13$ $\mathrm{mm}^{2} / \mathrm{d}$ between 60 to $80 \mathrm{~d}$ pp $(P=0.001)$.

\section{DISCUSSION}

The present study provides an overview of macroscopic and microscopic morphological changes of the rumen papillae in adult dairy cows during the dry period and subsequent $80 \mathrm{~d}$ of lactation and presents the first data showing the effect of postpartum concentrate build-up on rumen morphology. During the dry period, papilla surface area decreased and then increased rapidly again from d $3 \mathrm{pp}$ onwards. In line with our hypothesis, the rapid rate of increase of concentrate allowance created a temporary difference in FOM intake, affecting rumen papilla development. Rumen papilla surface area and width increased at a higher rate in the group with the rapid rate of increase of concentrate allowance. In contrast to our expectations, neither the thickness of the papillae nor the thickness of the epithelium were affected by the concentrate treatment.

In the present experiment, rumen papillae surface area and papilla width showed a $19 \%$ reduction in some $50 \mathrm{~d}$ during the pretreatment period, whereas DM and FOM intake did not change. Earlier work suggests rapid rumen papilla atrophy is possible, with an approximate $65 \%$ reduction in surface area over $14 \mathrm{~d}$ (Dirksen et al., 1984). However, the $65 \%$ reduction coincided with an approximate $50 \%$ decrease in $\mathrm{NE}_{\mathrm{L}}$ intake (86 to 41 $\mathrm{MJ} / \mathrm{d}$ ) suggesting the rate of atrophy is influenced by the magnitude in ration change. In contrast to the limited papilla atrophy during the dry period, large and rapid changes in papilla surface area occur during early lactation. Depending on concentrate treatment, papilla surface area increased by 9 to $16 \mathrm{~d}$ to approximately the surface area at $50 \mathrm{~d}$ ap and increased by a further $85 \%$ by $80 \mathrm{~d}$ pp. The time required for rumen papilla adaptation to reach a steady state after transition to a higher plane of nutrition varies. Six to 8 wk are often cited, based on the work of Dirksen et al. (1984) and Liebich et al. (1987), whereas Bannink et al. (2008) concluded less than 4 wk of adaptation is required, although these studies base their conclusions on different measurements and experimental conditions. In the present study, papilla surface area, length, and width appear to reach a steady state between 60 and $80 \mathrm{~d}$ pp. However, it is evident that papilla surface area increases rapidly when daily FOM intake increases rapidly. Therefore, discussing rumen adaptation in dairy cattle

(1) 
in terms of change per day in morphological variables under study compared with change per day in ration variables (such as FOM) seems more appropriate. The initial increase in change of daily FOM intake between 3 and $9 \mathrm{~d}$ pp coincided with growth of the rumen papillae. This implies a capacity for a quick initiation of a response by the rumen papillae to an increase in FOM intake. However, in group RAP, daily change in surface area almost doubled between 9 and $16 \mathrm{~d}$ pp compared with 3 to $9 \mathrm{~d} \mathrm{pp}$, whereas the change in daily FOM intake peaked between 3 to $9 \mathrm{~d} \mathrm{pp}$, indicating a lag effect in the maximum response of papilla surface area to ration changes. In group GRAD, the initial peak in change of daily FOM intake between 3 to $9 \mathrm{~d}$ pp was not followed by a peak in change in papilla surface area, but the papilla surface area showed almost linear growth up to $60 \mathrm{~d}$ pp. Daily change in FOM intake from 30 to 44 and 44 to $60 \mathrm{~d}$ pp, however, was much smaller than that from 9 to 16 and from 16 to $30 \mathrm{~d} p p$, also indicating a lag effect in the response of the rumen papillae in group GRAD. Obviously, the rumen papillae show a capacity for rapid growth, but the maximum response is delayed when compared with the changes in FOM. It remains unclear, however, why the capacity for rapid growth is not used later in lactation (especially in GRAD and to lesser extent in RAP) to reach a steady state in rumen papilla surface area in relation to the FOM intake earlier, as FOM intake was similar from $44 \mathrm{~d}$ pp onwards.

The lack of effect of rate of increase of concentrate allowance on histological variables suggests that rumen papillae proliferate in a similar manner when faced with a rapid or gradual rate of increase of concentrate allowance (Bannink et al., 2012) and, arguably, maintain a similar functional capacity per unit of surface area. In line with results of Steele et al. (2011) and Bannink et al. (2012), papilla thickness and the thickness of the epithelial layer in the middle decreased during the treatment period, although Steele et al. (2015) did not report a difference in epithelium thickness in the middle of the papillae when cows transitioned to a lactation ration. The thinner epithelium was maintained at the end of the experimental period, whereas the papilla surface area remained similar from $60 \mathrm{~d}$ onward. This suggests a thinner epithelium is also advantageous after absorption of VFA into the epithelium at the luminal side, either passively or by mediated transport (Aschenbach et al., 2011). Rumen papilla epithelium might be regarded as a functional syncytium, with cell-cell gap junctions allowing rapid diffusion between the apical and basal cell layers aided by a distinct distribution of pumps on the luminal and basal side of the epithelium (Graham and Simmons, 2005; Graham et al., 2007). A thinner epithelium reduces the distance VFA have to diffuse across before transfer from the epithelium into the blood, arguably enhancing the VFA absorption capacity.

A higher ratio between the stratum basale and stratum corneum indicates more extensive folding of the basal membrane and reflects the extent of rete-peg formation in the epithelium. The increase in this ratio at 9 d pp is in accordance with Dirksen et al. (1984), Liebich

Table 4. Least square means of total papilla thickness at the tip and at the middle, epithelium thickness at the papilla middle, and ratio of stratum basale to stratum corneum for rapid rate of increase $(1.0 \mathrm{~kg}$ of $\mathrm{DM} / \mathrm{d})$ of concentrate allowance $(\mathrm{RAP} ; \mathrm{n}=6)$ and gradual rate of increase $(0.25 \mathrm{~kg}$ of $\mathrm{DM} / \mathrm{d})$ of concentrate allowance $(\mathrm{GRAD} ; \mathrm{n}=6)$ treatments

\begin{tabular}{|c|c|c|c|c|c|c|c|c|c|c|c|c|c|c|c|}
\hline \multirow{2}{*}{ Item } & \multicolumn{10}{|c|}{$\mathrm{D}^{1}$} & \multirow{2}{*}{$\mathrm{SE}^{2}$} & \multicolumn{4}{|c|}{ Fixed effects ${ }^{3}$} \\
\hline & \multicolumn{4}{|c|}{ Pretreatment period } & \multicolumn{6}{|c|}{ Treatment period } & & $\mathrm{T}$ & $\mathrm{D}$ & S & $\mathrm{T} \times \mathrm{D}$ \\
\hline \multicolumn{16}{|c|}{ Total papilla thickness tip, mm } \\
\hline $\begin{array}{l}\text { RAP } \\
\text { GRAD }\end{array}$ & 0.33 & 0.34 & 0.35 & 0.35 & $\begin{array}{l}0.36 \\
0.39\end{array}$ & $\begin{array}{l}0.34 \\
0.36\end{array}$ & $\begin{array}{l}0.33 \\
0.37\end{array}$ & $\begin{array}{l}0.31 \\
0.33\end{array}$ & $\begin{array}{l}0.32 \\
0.33\end{array}$ & $\begin{array}{l}0.30 \\
0.32\end{array}$ & 0.013 & 0.378 & $<0.001$ & 0.003 & 0.399 \\
\hline \multicolumn{16}{|c|}{ Epithelial thickness middle, $\mu \mathrm{m}$} \\
\hline $\begin{array}{l}\text { RAP } \\
\text { GRAD }\end{array}$ & 66 & 68 & 74 & 72 & $\begin{array}{l}73 \\
73\end{array}$ & $\begin{array}{l}71 \\
72\end{array}$ & $\begin{array}{l}69 \\
73\end{array}$ & $\begin{array}{l}65 \\
65\end{array}$ & $\begin{array}{l}68 \\
65\end{array}$ & $\begin{array}{l}66 \\
62\end{array}$ & 2.1 & 0.944 & 0.002 & 0.002 & 0.805 \\
\hline \multicolumn{16}{|c|}{ Ratio of length stratum basale to stratum corneum } \\
\hline $\begin{array}{l}\text { RAP } \\
\text { GRAD }\end{array}$ & 1.71 & 1.79 & 1.84 & 1.76 & $\begin{array}{l}1.95 \\
1.93\end{array}$ & $\begin{array}{l}1.71 \\
1.80\end{array}$ & $\begin{array}{l}1.67 \\
1.78\end{array}$ & $\begin{array}{l}1.58 \\
1.60\end{array}$ & $\begin{array}{l}1.68 \\
1.63\end{array}$ & $\begin{array}{l}1.63 \\
1.58\end{array}$ & 0.035 & 0.739 & $<0.001$ & $<0.001$ & 0.330 \\
\hline
\end{tabular}


A

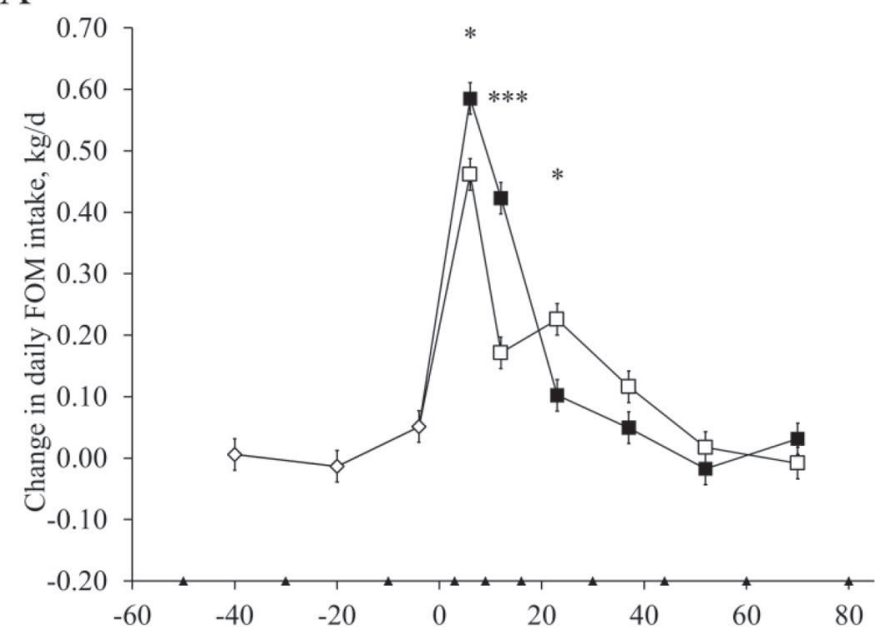

$\mathrm{B}$

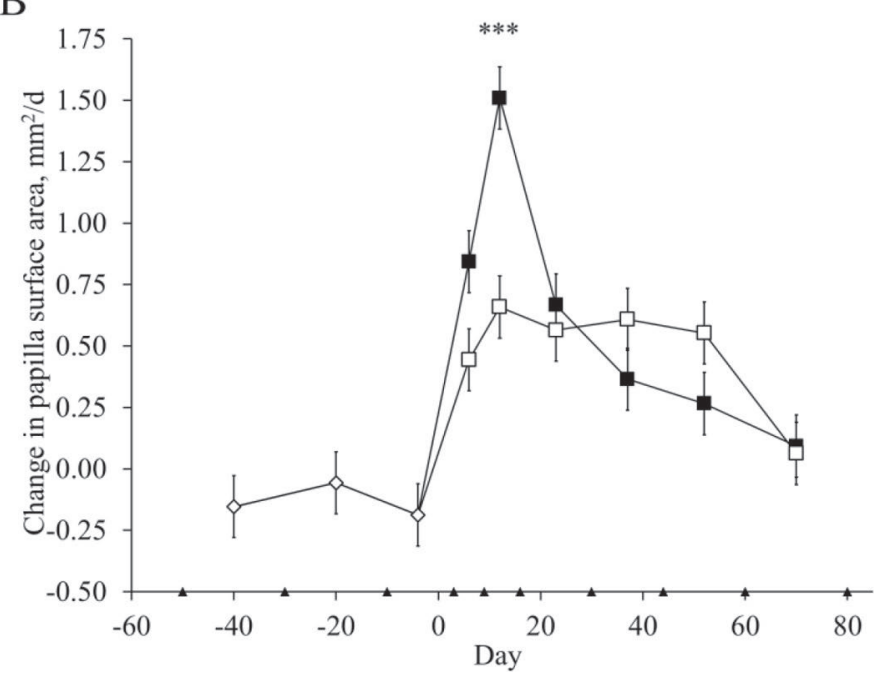

Figure 5. (A) Change in daily fermentable organic matter $(\mathrm{kg} / \mathrm{d}$; FOM) intake in the pretreatment period $(\diamond ; \mathrm{n}=12)$, and in the treatment period for a rapid (1.0 kg of DM/d; RAP, $\mathbf{\square}, \mathrm{n}=6)$ and gradual $(0.25 \mathrm{~kg}$ of $\mathrm{DM} / \mathrm{d} ; \mathrm{GRAD}, \square, \mathrm{n}=6)$ rate of increase of concentrate allowance. (B) Change in papilla surface area $\left(\mathrm{mm}^{2} / \mathrm{d}\right)$ for the pretreatment $(\diamond)$ and the treatment period (RAP, $\mathbf{c}, \mathrm{n}=6$; GRAD, $\square$, $\mathrm{n}=6$ ). Change in daily FOM intake and change in papilla surface area is calculated for the period between 2 subsequent sampling days (sampling days indicated by $\boldsymbol{\Lambda}$ ). Day $=$ day relative to calving. Values represent $\mathrm{LSM} \pm \mathrm{SE} .{ }^{*} P<0.050,{ }^{* * *} P<0.001$, significance of difference in LSM of RAP or GRAD.

et al. (1987), and Steele et al. (2015), who showed similar changes after switching cows to a higher plane of nutrition. Arguably, this increase is associated with the onset of papilla growth seen at this time (Figure 5B) and might reflect a high rate of cellular proliferation at the papilla tip, as suggested by Steele et al. (2015). The process responsible for the later decrease in the ratio remains unclear but might be associated with restructuring of the epithelium. The temporary larger stratum basale-to-stratum corneum ratio at $9 \mathrm{~d}$ pp might also have functional consequences. It can be speculated that more extensive folding of the stratum basale increases the capacity to maintain a large concentration gradient of VFA across the epithelium by increasing the capacity for efflux of VFA over the basal membrane to the capillaries with which it is closely associated (Dobson et al., 1956).

In the present study, manipulating the rate of increase of concentrate allowance created a difference in daily FOM intake as well as a greater intake of starch, sugar, and $\mathrm{NE}_{\mathrm{L}}$ at $16 \mathrm{~d}$ pp in group RAP. In general, higher supply of nutrients in early lactation increases daily milk production (Kokkonen et al., 2004). Therefore, in the present experiment we expected, but did not observe, an interaction between sampling day and concentrate treatment for milk production, with a greater milk production and earlier peak in production for cows in group RAP than in group GRAD. We fed the basal diet and concentrate separately, and intake of the basal diet (mainly silage) was greater in the GRAD than the RAP group. Similarly, Ingvartsen et al. (2001) did not observe positive effects of faster concentrate supply in early lactation on milk yield with separate feeding of silage and concentrate. They attributed this lack of response to a decline in silage intake with fast concentrate supply, whereas a complete diet feeding resulted in highest milk production in their trial. It should also be stressed that unintended systematic differences in milk production capacity between treatment groups, despite the random assignment of cows, cannot be ruled out because treatment groups were relatively small $(\mathrm{n}=6)$ and cows were blocked on expected calving date before random assignment to either one of the treatment groups.

The effects of the dry period ration, basal lactation ration, and concentrate treatment on rumen fluid affected total VFA concentration, VFA molar proportions, and $\mathrm{pH}$ of the rumen fluid, which is in agreement with earlier work (Dijkstra, 1994; Sutton et al., 2003; Bannink et al., 2008). All 3 major VFA likely affect rumen papillae development (Sander et al., 1959; Sakata and Tamate, 1979; Suarez et al., 2006), with butyric acid probably having the most pronounced effect (Sakata and Tamate, 1978; Shen et al., 2005; Malhi et al., 2013). Although the production rate of the different VFA influences their molar proportions in the rumen fluid (Dijkstra, 1994), no conclusions on proliferative effects of any specific VFA can be drawn based on VFA concentration and molar proportion alone.

In conclusion, our study clearly shows the relation between changes in FOM intake and papilla morphology (papilla length, width, thickness, surface area, and epithelium) in Holstein Friesian dairy cows, and these 
results were obtained under experimental conditions and with rations that reflect common dairy practice. During the 8-wk dry period, papilla surface area decreased, but, within 1 to $2 \mathrm{wk} \mathrm{pp}$, surface area returned to the level at the start of the dry period and continued to increase up to 8 to $9 \mathrm{wk}$ pp. Rate of increase of concentrate allowance after calving affected rate of increase of papilla surface area, indicating rumen papillae can mount a variable response to the level of increase of daily FOM intake.

\section{ACKNOWLEDGMENTS}

The authors acknowledge Dairy Campus staff (Lelystad, the Netherlands) for their technical support, Dirk Anjema (Lelystad, the Netherlands) for his assistance during the rumen cannulation procedures, and Sytske Jonkman (Leeuwarden, the Netherlands) for her assistance during the sampling procedures. The authors acknowledge the financial support of the Product Board Animal Feed (Zoetermeer, the Netherlands) and Dutch Dairy Board (Zoetermeer, the Netherlands).

\section{REFERENCES}

Andersen, J. B., J. Sehested, and K. L. Ingvartsen. 1999. Effect of dry cow feeding strategy on rumen $\mathrm{pH}$, concentration of volatile fatty acids and rumen epithelium development. Acta Agric. Scand. Anim. Sci. 49:149-155. http://dx.doi.org/10.1080/090647099424051.

Aschenbach, J. R., G. B. Penner, F. Stumpff, and G. Gäbel. 2011. Ruminant nutrition symposium: Role of fermentation acid absorption in the regulation of ruminal pH. J. Anim. Sci. 89:1092-1107.

Bannink, A., J. France, S. Lopez, W. J. J. Gerrits, E. Kebreab, S. Tamminga, and J. Dijkstra. 2008. Modelling the implications of feeding strategy on rumen fermentation and functioning of the rumen wall. Anim. Feed Sci. Technol. 143:3-26. http://dx.doi. org/10.1016/j.anifeedsci.2007.05.002.

Bannink, A., W. J. J. Gerrits, J. France, and J. Dijkstra. 2012. Variation in rumen fermentation and the rumen wall during the transition period in dairy cows. Anim. Feed Sci. Technol. 172:80-94. http://dx.doi.org/10.1016/j.anifeedsci.2011.12.010.

Bergman, E. N. 1990. Energy contributions of volatile fatty acids from the gastrointestinal tract in various species. Physiol. Rev. 70:567-590.

CVB. 2011. Chemische Samenstellingen en Nutritionele Waarden van Voedermiddelen (in Dutch). CVB (Centraal Veevoederbureau), The Hague, the Netherlands.

Dijkstra, J. 1994. Production and absorption of volatile fatty acids in the rumen. Livest. Prod. Sci. 39:61-69. http://dx.doi. org/10.1016/0301-6226(94)90154-6.

Dijkstra, J., H. Boer, J. Van Bruchem, M. Bruining, and S. Tamminga. 1993. Absorption of volatile fatty acids from the rumen of lactating dairy cows as influenced by volatile fatty acid concentration, $\mathrm{pH}$ and rumen liquid volume. Br. J. Nutr. 69:385-396. http:// dx.doi.org/10.1079/BJN19930041.

Dijkstra, J., J. L. Ellis, E. Kebreab, A. B. Strathe, S. López, J. France, and A. Bannink. 2012. Ruminal pH regulation and nutritional consequences of low pH. Anim. Feed Sci. Technol. 172:22-33. http:// dx.doi.org/10.1016/j.anifeedsci.2011.12.005.

Dirksen, G., H. G. Liebich, G. Brosi, H. Hagemeister, and E. Mayer. 1984. Morphologie der Pansenschleimhaut und Fettsäureresorption beim Rind-Bedeutende Faktoren für Gesundheit und
Leistung. Zentralbl. Veterinarmed. A 31:414-430. http://dx.doi. org/10.1111/j.1439-0442.1984.tb01300.x.

Dobson, M. J., W. C. B. Brown, A. Dobson, and A. T. Phillipson. 1956. A histological study of the organization of the rumen epithelium of sheep. Q. J. Exp. Physiol. Cogn. Med. Sci. 41:247-253.

Dyce, K. M., W. O. Sack, and C. J. G. Wensing. 1996. The abdomen of the ruminants. Pages 671-695 in Textbook of Veterinary Anatomy. 2nd ed. W.B. Saunders Company, Philadelphia, PA.

Graham, C., I. Gatherar, I. Haslam, M. Glanville, and N. L. Simmons. 2007. Expression and localization of monocarboxylate transporters and sodium/proton exchangers in bovine rumen epithelium. Am. J. Physiol. Regul. Integr. Comp. Physiol. 292:R997-R1007. http:// dx.doi.org/10.1152/ajpregu.00343.2006.

Graham, C., and N. L. Simmons. 2005. Functional organization of the bovine rumen epithelium. Am. J. Physiol. Regul. Integr. Comp. Physiol. 288:R173-R181. http://dx.doi.org/10.1152/ ajpregu.00425.2004.

Ingvartsen, K. L., O. Aaes, and J. B. Andersen. 2001. Effects of pattern of concentrate allocation in the dry period and early lactation on feed intake and lactational performance in dairy cows. Livest. Prod. Sci. 71:207-221. http://dx.doi.org/10.1016/S03016226(01)00192-0.

ISO. 1999a. Animal feeding stuffs - Determination of fat content. ISO 6492. International Organization for Standardization (ISO), Geneva, Switzerland.

ISO. 1999b. Animal feeding stuffs-Determination of moisture and other volatile matter content. ISO 6496. ISO, Geneva, Switzerland.

ISO. 1999c. Whole milk. Determination of milk fat, protein and lactose content-Guidance on the operation of mid-infrared instruments. ISO 9622. ISO, Geneva, Switzerland.

ISO. 2002. Animal feeding stuffs - Determination of crude ash. ISO 5984. ISO, Geneva, Switzerland.

ISO. 2004. Animal feeding stuffs - Enzymatic determination of total starch content. ISO 15914. ISO, Geneva, Switzerland.

ISO. 2005. Animal feeding stuffs-Determination of nitrogen content and calculation of crude protein content-Part 1: Kjeldahl method. ISO 5983-1. ISO, Geneva, Switzerland.

Kokkonen, T., A. Tesfa, M. Tuori, and L. Syrjälä-Qvist. 2004. Concentrate feeding strategy of dairy cows during transition period. Livest. Prod. Sci. 86:239-251. http://dx.doi.org/10.1016/j. livprodsci.2003.09.003.

Lesmeister, K. E., P. R. Tozer, and A. J. Heinrichs. 2004. Development and analysis of a rumen tissue sampling procedure. J. Dairy Sci. 87:1336-1344. http://dx.doi.org/10.3168/jds.S00220302(04)73283-X.

Liebich, H. G., G. Dirksen, A. Arbel, S. Dori, and E. Mayer. 1987. Fütterungsabhängige Veränderungen der Pansenschleimhaut von Hochleistungskühen im Zeitraum von der Trockenstellung bis acht Wochen postpartum. J. Vet. Med. Ser. A 34:661-672. http:// dx.doi.org/10.1111/j.1439-0442.1987.tb00329.x.

Littell, R. C., P. R. Henry, and C. B. Ammerman. 1998. Statistical analysis of repeated measures data using SAS procedures. J. Anim. Sci. 76:1216-1231.

Littell, R. C., G. A. Milliken, W. W. Stroup, R. D. Wolfinger, and O. Schabenberger. 2006. SAS for Mixed Models. 2nd Edition. SAS Institute Inc., Cary, NC.

Malhi, M., H. Gui, L. Yao, J. R. Aschenbach, G. Gäbel, and Z. Shen. 2013. Increased papillae growth and enhanced short-chain fatty acid absorption in the rumen of goats are associated with transient increases in cyclin D1 expression after ruminal butyrate infusion. J. Dairy Sci. 96:7603-7616. http://dx.doi.org/10.3168/jds.20136700.

Martens, H., I. Rabbani, Z. Shen, F. Stumpff, and C. Deiner. 2012. Changes in rumen absorption processes during transition. Anim. Feed Sci. Technol. 172:95-102. http://dx.doi.org/10.1016/j. anifeedsci.2011.12.011.

Odongo, N. E., O. AlZahal, M. I. Lindinger, T. F. Duffield, E. V. Valdes, S. P. Terrell, and B. W. McBride. 2006. Effects of mild heat stress and grain challenge on acid-base balance and rumen tissue histology in lambs. J. Anim. Sci. 84:447-455. 
Penner, G. B., J. R. Aschenbach, G. Gäbel, R. Rackwitz, and M. Oba. 2009. Epithelial capacity for apical uptake of short chain fatty acids is a key determinant for intraruminal $\mathrm{pH}$ and the susceptibility to subacute ruminal acidosis in sheep. J. Nutr. 139:1714-1720. http://dx.doi.org/10.3945/jn.109.108506.

Penner, G. B., M. A. Steele, J. R. Aschenbach, and B. W. McBride. 2011. Ruminant nutrition symposium: Molecular adaptation of ruminal epithelia to highly fermentable diets. J. Anim. Sci. 89:11081119.

Reynolds, C. K., B. Durst, B. Lupoli, D. J. Humphries, and D. E. Beever. 2004. Visceral tissue mass and rumen volume in dairy cows during the transition from late gestation to early lactation. J. Dairy Sci. 87:961-971. http://dx.doi.org/10.3168/jds.S00220302(04)73240-3.

Sakata, T., and H. Tamate. 1978. Rumen epithelial cell proliferation accelerated by rapid increase in intraruminal butyrate. J. Dairy Sci. 61:1109-1113. http://dx.doi.org/10.3168/jds.S00220302(78)83694-7.

Sakata, T., and H. Tamate. 1979. Rumen epithelium cell proliferation accelerated by propionate and acetate. J. Dairy Sci. 62:49-52. http://dx.doi.org/10.3168/jds.S0022-0302(79)83200-2.

Sander, E. G., R. G. Warner, H. N. Harrison, and J. K. Loosli. 1959. The stimulatory effect of sodium butyrate and sodium propionate on the development of rumen mucosa in the young calf. J. Dairy Sci. 42:1600-1605. http://dx.doi.org/10.3168/jds.S00220302(59)90772-6.

Scocco, P., A. Brusaferro, and A. Catorci. 2012. Comparison between two different methods for evaluating rumen papillae measures related to different diets. Microsc. Res. Tech. 75:884-889. http:// dx.doi.org/10.1002/jemt.22008.

Shen, Z., S. Kuhla, R. Zitnan, H. M. Seyfert, F. Schneider, H. Hagemeister, A. Chudy, B. Löhrke, J. W. Blum, H. M. Hammon, and J. Voigt. 2005. Intraruminal infusion of n-butyric acid induces an increase of ruminal papillae size independent of IGF-1 system in castrated bulls. Arch. Anim. Nutr. 59:213-225. http://dx.doi. org $/ 10.1080 / 17450390500216894$.

Steele, M. A., J. Croom, M. Kahler, O. AlZahal, S. E. Hook, K. Plaizier, and B. W. McBride. 2011. Bovine rumen epithelium undergoes rapid structural adaptations during grain-induced subacute ruminal acidosis. Am. J. Physiol. Regul. Integr. Comp. Physiol. 300:R1515-R1523. http://dx.doi.org/10.1152/ajpregu.00120.2010.

Steele, M. A., C. Schiestel, O. AlZahal, L. Dionissopoulos, A. H. Laarman, J. C. Matthews, and B. W. McBride. 2015. The periparturient period is associated with structural and transcriptomic adaptations of rumen papillae in dairy cattle. J. Dairy Sci. 98:2583-2595. http://dx.doi.org/10.3168/jds.2014-8640.
Storm, A. C., N. B. Kristensen, and M. D. Hanigan. 2012. A model of ruminal volatile fatty acid absorption kinetics and rumen epithelial blood flow in lactating Holstein cows. J. Dairy Sci. 95:2919-2934. http://dx.doi.org/10.3168/jds.2011-4239.

Suárez, B. J., C. G. Van Reenen, W. J. Gerrits, N. Stockhofe, A. M van Vuuren, and J. Dijkstra. 2006. Effects of supplementing concentrates differing in carbohydrate composition in veal calf diets: II. Rumen development. J. Dairy Sci. 89:4376-4386. http://dx.doi. org/10.3168/jds.S0022-0302(06)72484-5.

Sutton, J. D., M. S. Dhanoa, S. V. Morant, J. France, D. J. Napper, and E. Schuller. 2003. Rates of production of acetate, propionate, and butyrate in the rumen of lactating dairy cows given normal and low-roughage diets. J. Dairy Sci. 86:3620-3633. http://dx.doi. org/10.3168/jds.S0022-0302(03)73968-X.

Sutton, J. D., A. D. McGilliard, and N. L. Jacobson. 1963. Functional development of rumen mucosa. I. Absorptive ability. J. Dairy Sci. 46:426-436. http://dx.doi.org/10.3168/jds.S0022-0302(63)890682 .

Tamate, H., A. D. McGilliard, N. L. Jacobson, and R. Getty. 1962. Effect of various dietaries on the anatomical development of the stomach in the calf. J. Dairy Sci. 45:408-420. http://dx.doi. org/10.3168/jds.S0022-0302(62)89406-5.

Tamminga, S., W. M. Van Straalen, A. P. J. Subnel, R. G. M. Meijer, A. Steg, C. J. G. Wever, and M. C. Blok. 1994. The Dutch protein evaluation system: the DVE/OEB-system. Livest. Prod. Sci. 40:139-155. http://dx.doi.org/10.1016/0301-6226(94)90043-4.

Van Es, A. J. H. 1978. Feed evaluation for ruminants. I. The systems in use from May 1977-onwards in The Netherlands. Livest. Prod. Sci. 5:331-345. http://dx.doi.org/10.1016/0301-6226(78)90029-5.

van Gastelen, S., E. C. Antunes-Fernandes, K. A. Hettinga, G. Klop, S. J. J. Alferink, W. H. Hendriks, and J. Dijkstra. 2015. Enteric methane production, rumen volatile fatty acid concentrations, and milk fatty acid composition in lactating Holstein-Friesian cows fed grass silage- or corn silage-based diets. J. Dairy Sci. 98:1915-1927. http://dx.doi.org/10.3168/jds.2014-8552.

Van Soest, P. J., J. B. Robertson, and B. A. Lewis. 1991. Methods for dietary fiber, neutral detergent fiber, and nonstarch polysaccharides in relation to animal nutrition. J. Dairy Sci. 74:3583-3597. http://dx.doi.org/10.3168/jds.S0022-0302(91)78551-2.

van Vuuren, A. M., C. J. Van Der Koelen, H. Valk, and H. De Visser. 1993. Effects of partial replacement of ryegrass by low protein feeds on rumen fermentation and nitrogen loss by dairy cows. J. Dairy Sci. 76:2982-2993. http://dx.doi.org/10.3168/jds.S00220302(93)77637-7. 